Available online at: http://journal.uny.ac.id/index.php/jppm

JPPM (Jurnal Pendidikan dan Pemberdayaan Masyarakat)

$8(1), 2021,67-75$

\title{
Communication of Parents and Early Childhood to Build Confidence in The Pandemic Covid-19
}

\author{
Eka Aryani \\ Universitas Mercu Buana Yogyakarta, Jl. Raya Wates - Jogjakarta, Yogyakarta, Indonesia \\ * Corresponding Atuthor Email: eka@mercubuana-yogya.ac.id, Telp: +6285729252521
}

\section{Received: 21 October 2020; Revised: 19 February 2021; Accepted: 19 February 2021}

\begin{abstract}
This study uses qualitative research, with data collection methods using interviews, observation, and documentation. Data analysis techniques using the Speadley model. The data validity technique uses triangulation. This research focuses on parental communication in building self-confidence in early childhood during the co-19 pandemic. Communication is an important requirement for children, especially to increase the confidence of early childhood. Based on research in Margorejo Village, Tempel Subdistrict, from 20 samples obtained a comparison data of $69 \%$ of parents applying democratic communication patterns, $31 \%$ of parents applying permissive communication patterns, and $29 \%$ of parents applying authoritarian communication patterns. Early childhood who have high self confidence comes from parents who implement democratic communication.
\end{abstract}

Keywords: Confidence, Communication, Early childhood, Pandemic Covid 19

\section{Komunikasi Orang Tua dan Anak Usia Dini Membangun Keyakinan di Tengah Pandemi Covid-19}

\begin{abstract}
Abstrak: Penelitian ini menggunakan penelitian kualitatif, dengan metode pengumpulan data menggunakan wawancara, observasi, dan dokumentasi. Teknik analisis data menggunakan model Speadley. Teknik keabsahan data menggunakan triangulasi. Penelitian ini berfokus pada komunikasi orang tua dalam membangun rasa percaya diri pada anak usia dini di masa pandemi covid-19. Komunikasi merupakan kebutuhan penting bagi anak, terutama untuk meningkatkan kepercayaan diri anak usia dini. Berdasarkan penelitian di Desa Margorejo Kecamatan Tempel, dari 20 sampel diperoleh data perbandingan $69 \%$ orang tua menerapkan pola komunikasi demokratis, $31 \%$ orang tua menerapkan pola komunikasi permisif, dan $29 \%$ orang tua menerapkan pola komunikasi otoriter. Anak usia dini yang memiliki rasa percaya diri yang tinggi berasal dari orang tua yang menerapkan komunikasi demokratis.
\end{abstract}

Kata Kunci: Percaya Diri, Komunikasi, Anak Usia Dini, Pandemi Covid 19

How to Cite: Aryani E. (2021). Communication of Parents and Early Childhood to Build Confidence in The Pandemic Covid-19. JPPM (Jurnal Pendidikan dan Pemberdayaan Masyarakat), 8(1), 67-75.

Doi: https://doi.org/10.21831/jppm.v8i1.35211 


\section{INTRODUCTION}

Since the stipulation of Covid-19 as a pandemic, the Government has issued Minister of Education and Culture Circular No. 4 of 2020 which stipulates the rules of learning from home for school children and work from home for teachers. This condition is unexpected thing for teachers, parents, and children. Teachers, parents, and children suddenly have to find ways to keep the learning process going so that children's development remains optimal even though they are still at home .

The current situation demands maximum involvement of parents and communicates both with children and teachers who are more intense in reporting their child's progress. Parents will be more active in working with teachers when accompanying children at home. It can also be said that the covid-19 pandemic situation restores the essence of children's education in the family.

Family is the first environment for children. It is in this family environment that children receive their first and foremost education. The main task of the family is to lay the foundation for the education of moral-religion and children's character. According to Zuharini, et al a family environment laid the foundations of personality for children age prematurely. It is at this age that children are very sensitive to the influence of the surrounding environment (Baharun, 2016). The intense interaction between children and adults who have a special relationship with children will have a significant positive effect on children's growth and development.

The role of parents is very important when children start schooling at home. Because parents or family are basically the first place of education for children. This is in accordance with Mutiah's opinion, which states that caring for, fostering, and educating children at home is an obligation for every parent in an effort to form a child's personality (Mutiah, 2012). Parents are tasked with helping children in preparing the media that will be used by children, accompanying the learning process and many more roles of parents who can maximize the teaching and learning process at home through online.

Assistance of parents in communicating with children and in learning from home besides helping children in the learning process will also build intense communication with children. This intense communication will build children's creativity through various useful joint activities (Mutiah, 2012). The role of teachers and parents is fundamental in supporting the process of children learning at home. Both must build collaboration in order to maximize children's learning activities.

One effort in shaping the character of the child that is to build confidence in children. In this case, parent-child communication is very important. As stated by Suryo Subroto (via Rahman, 2013), communication between parents and their children is very important for the development of children's personalities in building children's self-confidence. If parental communication has a good effect on their children, it will cause the child to develop well too. The atmosphere of communication between parents at home has an important role in determining children's life at school. Parents must make the house a place to communicate intensely with their children.

Children are the nation's assets in the future. The better the child's personality, the better the future life of the nation. Vice versa, if the child's personality is bad, it will also damage the life of the nation to come. Communication patterns have a strong influence in helping early childhood amid the Covid-19 pandemic. According to Rahman (2013), parent-child communication is said to be effective when both parties are close to each other, like each other and communication between the two is fun and there is openness so that self-confidence grows. Effective communication is based on openness and positive support for children so that children can properly accept what parents say. Parents' communication has a good effect on their children. Communication to parents is the process of conveying information between children and parents, giving rise to certain attention and effects. The signs of effective communication 


\section{JPPM (Jurnal Pendidikan dan Pemberdayaan Masyarakat), 8 (1), 2021 - 69}

Eka Aryani

are understanding, fun, influencing attitudes, good social relationships, and actions. If in communication there are these signs it can be said to be effective.

An effective parent communication becomes a way appropriate to build confidence in children. The role of parents in building confidence in children during the pandemic covid-19 of which is to show respect, be a good listener, giving the opportunity to help, sorting praise parents of children, help children to be optimistic, cultivate interests and talents of children, invites solving problems, looking for ways to help others, and directing to prepare for the future. Self-confidence is an important aspect of human life. Self-confidence is needed in a child's life as a provision to overcome every challenge and problematic life in the future.

Jaccard \& Dittus (via Fauzi and Herdina, 2014:98) say that honest and understanding communication between parents and children can create comfort between the two, so that it will be easier for both of them to convey and capture information. Ginoot (via Mufida, 2016:28) argues that the way of communicating between parents and children must be based on respect and skill, which means: first warning, greeting should not hurt the child's self-esteem or parents. Second, we must first show understanding to the child, then give advice or orders. Furthermore, Andrianto (2011:13-17) describes a form of communication parents and children by way of parenting is (a) Communication Authoritarian , Children must obey the will of his mother and father. When communicating, parents talk more than they listen, this is the nature of most mothers and fathers. Tend to provide advice and direction, regardless of the differences between our past and childhood. Do not want to hear and understand the problems experienced by children first. Do not give opportunities to children to express opinions and always blame children. (b) Democratic Communication, Parents are able to make gathering and talking with family a memorable time for their children, even if it's only a few minutes a day. What parents need to understand is that every child has a desire to be respected and has different opinions. (c) Permissive Communication , Parents do not use the right to make rules and tend to impose punishment on children, but do not guide and give the role of children in the family.

According to Harlock (via Mufidah, 2016:25) communicative parents are doing various things for children, being quite permissive and flexible, fair and disciplined respecting individual children, creating a warm atmosphere, not an atmosphere full of fear, setting a good example, being friends. and accompanying children in various activities, being kind for most of the time, showing affection for the child, sympathizing when the child is sad or experiencing difficulties, trying to make a happy home, providing age-appropriate independence.

Parents play a very important role in shaping the character of a child. One effort in shaping the character of the child that is to build confidence in children. According to Hakim (via Rahayu 2013:63), confidence is a person's belief in all aspects of his / her strengths and makes his ability to achieve various life goals. Children are said to be confident if they dare to do something good for themselves according to their abilities.

Confidence according to Lauster (2002:4) is an attitude or belief in one's own abilities so that in their actions they are not too anxious, feel free to do things according to their wishes and responsibilities for their actions, are polite in interacting with others, have an achievement drive and can recognize their strengths and weaknesses. Lauster describes that people who have selfconfidence have the characteristics of selflessness (tolerance), do not need the encouragement of others, are optimistic and happy.

According to Rahman (2013) self-confidence can be interpreted as a belief in oneself that is owned by each person in his life and how that person sees himself as a whole by referring to the self-concept. Rahman (2013) also adding that self-confidence is a mental or psychological condition of a person that gives strong confidence in him to do or take an action. People who are not confident have a negative self-concept, do not believe in their abilities, because they often close themselves.

The characteristics of children who have high trust according to Yoder and Proctor (via Rahayu, 2013:69) are: a) Active children but not excessive, b) Not easily influenced by other 
people, c) Easy to get along, d) Positive thinking, e) Full of responsibility, f) Energetic and not easy to give up, g) Can work together, h) Have a leadership spirit. Meanwhile, according to the Judge (via Rahman, 2013: 379) children who have a lack of self-confidence are (a) Easily anxious in facing problems with a certain level of difficulty (b) Have weaknesses or deficiencies in terms of mental, physical, social, or economic (c) Difficult to neutralize the emergence of tension in a situation of nervousness and sometimes stuttering (d) Has a poor family educational background (e) Has poor development since childhood (f) Has less advantages in certain areas and does not know how to Developing yourself to have certain advantages (g) Often isolating from groups that he thinks are more than himself (h) Easy to despair (i) Tend to depend on other people in overcoming problems (j) Have experienced trauma (k) Often react negatively in facing problems, for example by avoiding responsibility or isolating oneself, which causes selfinsecurity to get worse.

Added by Hakim (2002) which mentions several characteristics or characteristics of individuals who have proportional self-confidence including (a) Always feel calm when doing something, (b) Have adequate potential and abilities, (c) Be able to neutralize tensions that arise in various situations, (d) Able to adapt and communicate in various situations, (e) Have sufficient mental and physical conditions to support their appearance, (f) Have sufficient intelligence, (g) Have sufficient levels of formal education, (h ) Have other skills and skills that support their life, for example foreign language skills, (i) Have the ability to socialize, (j) Have a good family educational background, $(\mathrm{k})$ Have life experiences that forge mentally to be strong and resilient in dealing with various life trials, (l) always react positively in facing various problems, for example by staying strong, patient and steadfast facing tough life problems actually strengthens one's self-confidence.

Respect for yourself is the most important thing in building confidence in yourself. Believe in abilities, believe in your own strengths and weaknesses. And individuals who have selfconfidence will finally be able to value themselves positively. Confidence has several aspects. Lauster (2002) suggests aspects of self-confidence, among others: believe in one's own abilities, act independently in making decisions, have a positive sense of yourself, dare to express opinions. Furthermore, the regulation of the minister of education and culture of the republic of Indonesia number 137 of 2014 describes the achievement of child development based on age. Development of children aged 3-4 years is: participating in activities in an activity, imitating what adults do, reacting to things that are not right (angry when disturbed), say verbally.

Self-confidence in children cannot be separated from the influence of the environment and parental care. Building children's self-confidence according to Ghofar (2011:187), the way parents build children's self-confidence, namely by (a) Providing opportunities for children to express their feelings and opinions, (b) Respecting children's feelings and opinions, (c) Involving children in planning activities in the family, (d) Providing opportunities for children to express themselves through pictures or other creativity, (e) Appreciating the children's work by sticking on the wall, (f) Guiding children in improving the development of spoken and written language, (g) If children do wrong, reprimand with affection, (h) Not embarrass the child or blame the child in public, (i) Give the child the opportunity to take responsibility for his needs according to his ability, (j) Give the child the opportunity to help others.

Meanwhile, according to Hakim (2002) the way to grow children's self-confidence from an early age is by (a) Giving good positive words to children, avoiding using negative words that can make children feel inferior, (b) Do not be overprotective in giving words of praise to children, (c) Do not have too many restrictions, so that the child will be afraid of themselves, (d) Do not target something to the child, (e) Teach children as early as possible to participate in competence, dare to appear in an activity, (f) Give children Sufficient love and attention, (g) Train children's emotional sensitivity by giving freedom to express feelings.

Research conducted by Rahman is about the role of parents in building self-confidence in early childhood. The results of this study show that parents play a very important role in shaping 


\section{JPPM (Jurnal Pendidikan dan Pemberdayaan Masyarakat), 8 (1), 2021 - 71}

Eka Aryani

the character of a child. One of the efforts to build this character is to build self-confidence in children.

Another study was conducted by Firanda (2012), which states that self-confidence is like a plant, if the child's confident shoots are cared for, and nurtured with love and love, the shoots will grow and develop. Likewise, self-confidence in children can be built through good communication between parents and children. Parent and child communication can be done by using positive words and avoiding negative words that can damage the child's self- confidence.

Based on the explanation above, the researcher will analyze with qualitative research with the title " Communication of Parents and Early Childhood to Build Confidence in The Pandemic Covid-19".

\section{METHOD}

The method used in this research is qualitative method. The qualitative method according to Bogdan and Taylor (Moleong, 2011:4) is a research procedure that produces descriptive data in the form of written or spoken words from people and observable behavior. This type of research is a descriptive study that describes the communication between parents and children to build self-confidence in early childhood during the Covid-19 pandemic. According to Sugiyono (2017:15) that descriptive qualitative research is a research method based on the philosophy of postpositivism which is usually used to examine natural objective conditions where the researcher acts as a key instrument.

The research subjects were early childhood, aged 2-4 years in Margorejo Village, Tempel District . Margorejo Village is located in Tempel District, Sleman Regency, Yogyakarta Special Region. Data collection methods are using interviews, observation, and documentation. Interviews are an important part of qualitative research so that researchers can directly obtain data from various informants. Qualitative research makes it possible to combine observation techniques with interviews. As stated by Moleong (2011) states that in a qualitative study, observation alone is inadequate, that is why observations must be complemented by interviews.

Observation or observation is an important element in qualitative research, observation in a simple concept is a process or initial activity carried out by researchers to be able to find out the conditions, the reality of the research field. In contrast to the simple concept referred to, observation as suggested by Sugiyono (2017) is observing and listening to a person's behavior for some time, without manipulating or controlling and recording findings that allow or qualify for use in the act of interpreting analysis. The method of observation is very important in the qualitative research tradition because it is through observation that various forms of events, events, circumstances, actions that pattern from day to day in society are recognized. From there it is recognized which ones are very common or common, for whom, when, where and so on.

In qualitative research the data analysis process takes place before the researcher goes to the field, then during the field and after in the field, as stated by Sugiyono (2017:90) that the analysis has started since it was formulated and explained the problem, before going into the field and continues until writing research result. Meanwhile, data analysis according to Bogdan and Biklen (Maleong, 2011:248) is an effort made by working with data, organizing data, sorting it into manageable units, synthesizing it, looking for and finding patterns, finding what is important and what to learn, and decide what to tell others. The data validity technique used data triangulation. Data analysis techniques used the Spradley model (domain analysis, taxonomy, components, and cultural themes analysis). 


\section{JPPM (Jurnal Pendidikan dan Pemberdayaan Masyarakat), 8 (1), 2021 - 72}

Lely Masruroh, Erni Munastiwi

\section{RESULTS AND DISCUSSION}

Education in early childhood basically includes all the efforts and actions taken by educators and parents in the care, nurturing and education of children by creating an aura and an environment where children can explore experiences that provide opportunities for them to know and understand the learning experiences they have acquired. from the environment, through observing, imitating, and experimenting which takes place repeatedly and involves all the potential and intelligence of the child (Sujiono, 2009). Therefore, education in children must provide opportunities for children to get to know their environment. The education given to children is needed to be able to develop the potential of the child to be optimal.

Since the Covid 19 pandemic, children's education has been carried out remotely. Distance learning is carried out by utilizing existing technology so that children and parents can still interact with the teacher. However, the implementation of distance education does not always run smoothly, especially in early childhood education. In fact, there are still many complaints from teachers regarding difficulties in operating computers, accessing internet networks, unstable internet, difficulty communicating messages to parents, difficulties in preparing simple and suitable lesson plans for children to implement at home through parents, and also teacher difficulties in conducting assessments. on children's learning outcomes at home. On the other hand, complaints also come from parents, namely the difficulty of assisting children to learn because they do not understand how, are not used to using digital technology for children's learning, and do not understand the meaning of the message conveyed by the teacher.

The policy regarding learning at home not only demands learning innovations carried out by the teacher but also demands maximizing the role of parents in caring for, accompanying, and facilitating children in learning, caring, mentoring and the role of parents as educators now has a major influence on early childhood development (Sujiono, 2009). Learning carried out at home makes the role of parents very important. Parents must be able to facilitate learning activities carried out by children. This is in accordance with Iriani's opinion which states that education should be carried out as early as possible at home, the role and responsibility lies with the parents because parents are the main educators in the family, not just an intellectual issue but education for the formation of a noble personality. This role is often referred to as the education of children in the family.

Family is very influential in the development of children's learning motivation, therefore children's education cannot be separated from their families, because the family is the first place where children learn to express themselves as social beings in interacting with their groups. The family, especially the parents, is the first foundation for children's development.

Parents during the Covid-19 pandemic not only functioned as the first and foremost place for children's education in shaping character, religious values and character but now have an additional role as a second teacher for children in learning at home. The important role of parents during the learning process from home is to maintain children's motivation, facilitate children's learning, foster children's creativity, supervise children, foster children's selfconfidence and evaluate learning outcomes.

Accompanying children when learning is something very important for children, namely being able to build closeness between parents and children, learning to invite them to discuss in order to find out how the child's thinking patterns. The important role of parents in accompanying children is (Sundari \& Yoridho, 2018): (1) The child feels not alone. Parents accompany children so that children feel not alone. Mentoring made by the parent makes the child will feel comfortable going to raise the confidence of children. When faced with problems, there are parents who will protect them (Sundari \& Yoridho, 2018). That way, children feel their parents care, protect and give love. This can increase the closeness of parents and children, will raise the child's self-confidence; (2) Parents as encouragement. Parents encourage children. This spirit can be in the form of words that cause encouragement in the child. As a medium for 


\section{JPPM (Jurnal Pendidikan dan Pemberdayaan Masyarakat), 8 (1), 2021 - 73}

Eka Aryani

encouragement, it is necessary to attach slogans or pearls of wisdom in early childhood learning to create a positive atmosphere in children. With these words the child is more confident in doing something; (3) Facilitating children's needs Parents can facilitate children's needs for learning activities at home so that children's development can remain optimal. Learning can be adjusted to what has been obtained from school, so that there is continuity between what children get at school and at home. This is in accordance with Latif's opinion, which states that parents can facilitate children's activities at home that are tailored to children's learning in educational institutions such as providing books according to the theme being discussed in schools / institutions, as well as toys that support learning according to the theme. in schools / institutions; (4) Place to discuss and ask Parents is the first social place for children. The role of parents at home can also be used as discussion partners. Children will be more open if their parents are also open and give free time to discuss. Children have great curiosity so that they will ask their parents anything. This is in accordance with Pebria's opinion, a child to maximize its potential needs someone to discuss it in order to provide answers to the child and motivate the child . Therefore, it is very important for parents to be able to spend time with children to discuss and answer questions from children; (5) Help identify yourself Knowing ourselves as a means makes it easier for us to understand others. Children build their identity with the closest people. This is where the role of parents to shape children's character and attitudes in order to form a good personality; (6) See and develop children's talents. Parents must and are responsible for discovering children's talents and interests, so that children are nurtured and educated, either directly by parents or through the help of others, such as teachers, according to their own children's talents and interests, so that children can obtain optimal learning achievement; (7) Creating an environment that is conducive to learning. Parents must be able to create a comfortable learning environment and atmosphere so that children can learn well. The learning atmosphere is created naturally (naturally), warm, interesting, and fun, thus the learning atmosphere will run naturally and not bind the child.

Communication patterns have a strong influence in helping early childhood amid the Covid-19 pandemic. According to Rahman (2013), parent-child communication is said to be effective if both parties are close to each other, like each other and communication between the two is fun and there is openness so that self-confidence grows. Effective communication is based on openness and positive support for children so that children can properly accept what parents say. Parents' communication has a good effect on their children. Communication to parents is the process of conveying information between children and parents, so as to cause certain attention and effects. The signs of effective communication are understanding, fun, influencing attitudes, good social relationships, and actions. If in communication there are these signs it can be said to be effective.

Effective parental communication is the right way to build children's self-confidence. The role of parents in building self-confidence in children during the Covid-19 pandemic includes showing respect, being good listeners, providing opportunities to help, sorting out parental praise for children, helping children to be optimistic, fostering children's interests and talents, invites solving problems, looking for ways to help others, and directing to prepare for the future. Self-confidence is an important aspect of human life. Self-confidence is needed in a child's life as a provision for overcoming every challenge and problematic life in the future.

Based on this explanation, parents are a key milestone in early childhood communication at home during the Covid-19 pandemic. Parents in Margorejo Village, Tempel District, give freedom to children to do activities, parents become good listeners and always invite children to discuss, respond to children's opinions and understand children and respect them. This communication pattern is a democratic communication pattern. Baumrind (via Prawistri, 2013:399) states that democratic communication patterns use rational and democratic approaches. Parents really pay attention to the needs of children and provide them with considerations of factors of interest and realistic needs. Parents simply do not comply with the

Copyright @ 2020, JPPM, ISSN 2355-1615 (print), ISSN 2477-2992 (online) 


\section{JPPM (Jurnal Pendidikan dan Pemberdayaan Masyarakat), 8 (1), 2021 - 74}

Lely Masruroh, Erni Munastiwi

wishes of the child, but at the same time teach the child about the needs that are important for his life. The characteristics are encouraging children to be able to stand alone, give praise to children, and be warm and loving. In this parenting style the child will feel appreciated because every treatment and problem can be discussed with parents who are always open to listening.

Supported by the statement of Hurlock (2014) Parental behavior in family life is (a) Parents as determinants of rules, (b) Children have the opportunity to ask the reasons why rules are made, (c) Children may take part in raising objections to existing regulations.

From the above information, the types of communication patterns of parents greatly affect children's creative attitudes and self-confidence, especially democratic communication patterns so that children have the enthusiasm to develop their talents. Not only parents who direct children to be creative and confident, but also teachers and the environment around them can also guide the achievement of children's talents and interests, so that children can be motivated according to their abilities.

$69 \%$ of parents in Margorejo Village, Tempel District, apply this communication pattern. Parents who apply this communication pattern have children who have self-confidence according to their age development stage.

The statement above is in accordance with what Rahman did in the Journal of Islamic Education Research, explaining that in building self-confidence in early childhood, a very important role is parents. The roles of parents in building children's self-confidence include: 1) Being a good listener; 2) Shows respect; 3) Give children the opportunity to help; 4) Train children's independence; 5) Sorting out praise from parents to children; 6) Helping children to be more optimistic; 7) Cultivate children's interests and talents; 8) Invite children to solve problems; 9) Look for ways to help others; 10) Give children the opportunity to gather with adults and; 11) Directing in order to prepare for the future.

The statement above is in accordance with Permatasari's (2016) research on the impact of parental communication patterns, as follows (a) Authoritarian communication patterns, namely children become closed, fearful, difficult to interact socially and tend to withdraw from social life; (b) This democratic communication pattern has a positive influence on children. namely making the spirit of learning, independent, having a good attitude and morals, good at socializing, confident, and responsible; (c) Permissive communication patterns have an impact on children, namely children are disobedient, aggressive, and want to win alone, children lack self-confidence and sufficient self-control. The best and most effective communication pattern to apply is a democratic communication pattern.

The development stage of early childhood self-confidence in Permedikbud number 137 of 2014 explains that children: 1) Participate in activities in an activity, 2) Imitate what adults do, 3) React to things that are not right (angry when disturbed), 4 ) Said verbally. Attitudes that reflect the confidence of early childhood in Permedikbud number 146 of 2014 explain that children: 1) Accustomed to greeting teachers when welcoming, 2) Dare to appear in front of friends, teachers, parents, and other social environments, 3) Dare to express opinions, 4) Dare to convey wishes, 5) Communicate with strangers with adult supervision, 6) Enjoy participating in joint activities.

\section{CONCLUSION}

Based on the research of parents of students in Margorejo Village, Tempel District, applying a democratic communication pattern of $69 \%$ with the child's level of self-confidence according to the stage of their age development. $31 \%$ of parents apply permissive communication patterns and $29 \%$ of parents apply authoritarian communication patterns. Parents who apply authoritarian and permissive communication patterns are confident that their children need guidance because they are starting to develop or have not yet appeared. 


\section{JPPM (Jurnal Pendidikan dan Pemberdayaan Masyarakat), 8 (1), 2021 - 75}

Eka Aryani

Based on the results of the research, the researcher can conclude that to build children's self-confidence by applying democratic communication patterns, according to Ghofar (2011:187), the way parents grow children's self-confidence is by providing opportunities for children to express their feelings and opinions, respect children's feelings and opinions, involves children in planning activities in the family, providing opportunities for children to express themselves through pictures or other creativity.

\section{REFERENCES}

Andrianto, Dedy. (2011). Communication with Aud. Jakarta: Directorate of Early Childhood Education Development, Directorate General of Nonformal and Informal Early Childhood Education, Ministry of National Education.

Baharun, Hasan. (2016). Application of Active Learning to Improve Student Learning Outcomes in Madrasahs. Journal of Education Vol. 2 No. 2.

Firanda. (2012). The Difference in Confidence Between Children Who Join Playgroup and Not Join Playgroup In Group A in Aisyiyah Bustanul Athfal 3 Kindergarten. Surabaya: State University of Surabaya.

Ghofar, Abdul . (2011). The Right Learning Style To Stimulate Children's Brains. Yogyakarta: Diglosia Printika.

Hakim, Thursan. (2002). Overcoming Insecurity . Jakarta: Puspa Swara.

Hurlock, Elizabeth. (2014). Developmental Psychology of a Life Throughout the Span of Life. Jakarta: Publisher Erlangga.

Lauster, Peter. (2002). Personality Test. Jakarta: Earth Literacy.

Moleong, LJ. (2011). Qualitative Research Methodology Revised Edition. Bandung: PT. Rosdakarya youth.

Mufidah, Hilmi. (2016). Communication Between Parents and Children and Its Effect on Child Behavior (Case Study at Al-Azharz Islamic Junior High School Pejaten, South Jakarta). Jakarta: Syarif Hidayatullah State Islamic University.

Mutiah, Diana. (2012). Early Childhood Play Psychology . Jakarta: Kencana Prenada Media Group.

Regulation of the Minister of Education and Culture Number 137 of 2014.

Permatasari. (2016). Parent-child communication model in shaping elementary school children's morale (case study on student guardians of MIN Columnayan Blitar Regency). Malang: Maulana Malik Ibrohim University.

Prawistri. (2013). Efforts to Increase the Confidence of Group B Children through Active Play Activities at Tk Pembina Bantul District. Yogyakarta: Yogyakarta State University .

Rahayu, Aprianti Yofita. (2013). Fostering Self Confidence Through Storytelling Activities. Jakarta: Index.

Rahman, Muzdalifah. (2013). The role of parents in building self-confidence in early childhood. Kudus: Journal of Islamic Education Research. Vol. 8, No. 2, August 2013.

Sugiyono. (2017). Quantitative Research Methods, Qualitative and $R$ \& D. Bandung: Alvabeta Publishers.

Sujiono, Yuliani Nurani. (2009). Basic Concepts of Early Childhood Education. Jakarta: PT Index. 